\title{
Organizational structure in process-based organizations
}

Citation for published version (APA):

Vanhaverbeke, W. P. M., \& Torremans, H. (1998). Organizational structure in process-based organizations. NIBOR, Netherlands Institute of Business Organization and Strategy Research. NIBOR Research Memorandum No. 05 https://doi.org/10.26481/umanib.1998005

Document status and date:

Published: 01/01/1998

DOI:

10.26481/umanib.1998005

Document Version:

Publisher's PDF, also known as Version of record

\section{Please check the document version of this publication:}

- A submitted manuscript is the version of the article upon submission and before peer-review. There can be important differences between the submitted version and the official published version of record.

People interested in the research are advised to contact the author for the final version of the publication, or visit the DOI to the publisher's website.

- The final author version and the galley proof are versions of the publication after peer review.

- The final published version features the final layout of the paper including the volume, issue and page numbers.

Link to publication

\footnotetext{
General rights rights.

- You may freely distribute the URL identifying the publication in the public portal. please follow below link for the End User Agreement:

www.umlib.nl/taverne-license

Take down policy

If you believe that this document breaches copyright please contact us at:

repository@maastrichtuniversity.nl

providing details and we will investigate your claim.
}

Copyright and moral rights for the publications made accessible in the public portal are retained by the authors and/or other copyright owners and it is a condition of accessing publications that users recognise and abide by the legal requirements associated with these

- Users may download and print one copy of any publication from the public portal for the purpose of private study or research.

- You may not further distribute the material or use it for any profit-making activity or commercial gain

If the publication is distributed under the terms of Article $25 \mathrm{fa}$ of the Dutch Copyright Act, indicated by the "Taverne" license above, 


\title{
ORGANIZATIONAL STRUCTURE IN PROCESS-BASED ORGANIZATIONS
}

\author{
NIBOR / RM / 1998 / 05
}

\author{
Wim Vanhaverbeke \\ NIBOR - MW ORG \\ Universiteit Maastricht \\ P.O. Box 616 \\ 6200 MD Maastricht \\ The Netherlands \\ Tel: $\quad+31433883805$ \\ Fax: + 31433258495 \\ e-mail : w.vanhaverbeke@mw.unimaas.nl
}

\author{
Huub Torremans \\ Rijnconsult \\ P.O. Box 9100 \\ 6882 HA Velp \\ The Netherlands \\ Tel : $\quad+31263848591$ \\ Fax: $\quad+31263848588$ \\ e-mail: huub.torremans@ rijnconsult.nl
}

\section{Autobiographical note:}

Wim Vanhaverbeke $\left(1959^{\circ}\right)$ is associate professor at the University of Maastricht. He obtained a DBA-title at the IESE-business school in Barcelona in 1995. He teaches innovation management and change management at the University Maastricht. Main publications about strategic alliance and network competition, and regional economics.

Huub Torremans $\left(1961^{\circ}\right)$ is managing partner with Rijnconsult, a dutch consultancy firm (150 p) that also participates in ACE (Allied consultants Europe). He obtained a MBA-title at the University of Technology in Eindhoven in 1984. His consulting experiences ranges from manufacturing industry to financial service companies and government. Main publications about performance management and process management.

\begin{abstract}
:
This paper investigates the role of the organization structure in process-based organizations. We argue that companies cannot be designed upon organizational processes only or that process management can be simply imposed as an additional structural dimension on top of the existing functional or product dimension. It is more promising to consider process-based companies as organizations with a multidimensional structure with process ownership as a dominant dimension. The paper focuses on a number of consequences of the implementation of process-based organization structures. First, the complementary role of different types of processes is clarified. Second, we focus on the question how processes can be translated into the design of organizational units. Two key ideas underpin a process-based organizational structure. First, organizational units are organized around core processes. Second, other processes are added to these units minimizing the necessity of cross-unit coordination. This has several implications for planning and control activities and the way how process-based business units fit together to create a performing corporation. The latter can no longer be conceived within the traditional strategy-
\end{abstract}


structure paradigm because of the fundamentally different role of middle and top managers.

Key words: process-based organization; reengineering; organizational structure; changing management roles

\title{
ORGANIZATIONAL STRUCTURE IN PROCESS-BASED ORGANIZATIONS
}

\author{
Wim P.M. Vanhaverbeke and Huub M.P. Torremans \\ July 1998
}

Paper prepared for the $14^{\text {th }}$ EGOS-Conference in Maastricht 9-11 July 1998

\section{INTRODUCTION}

Business processes are central to the functioning of an organization. Yet, they have been neglected for a long time in managerial studies mainly due to the fact departments in companies are structured in a functional or product oriented way. Several companies are breaking away from this type of organizations and intend to establish process-based organizations in order to cope with the increasing complexity and dynamics of the economic environment. This shift has clear implications for the organizational structure. Remarkably enough one finds almost no comments in the business process reengineering and change management literature about the interaction between these efforts to realign a company along processes and their impact on the organizational structure.

A considerable number of consultancy firms and scholars on management have argued that a process-based organization is a powerful answer to the problems functional and product oriented structured firms could not cope with. Process-based organizations also have a completely different organizational structure than structured-based ones. However, we will argue that processes cannot become the only basis for organizational structure: Functional skills as well as product management remain important to a process orientation. A purely process-based organization gets into problems with activities crossing different processes and cross-process integration might be necessary. Therefore, a multidimensional structure with process ownership as a key dimension seems to more interesting than a purely process-based organization. Process ownership should be a dominant dimension: A frequent mistake is to impose process management as an additional structural dimension on top of the existing functional or product dimension. In that way, being structured in a process-based way conflicts with the other dimensions and process responsibility does not get any organizational legitimacy.

We distinguish two key ideas underpinning a viable process-based organization. First, a company is divided into basic organizational units which are organized around core processes. Second, other type of processes are added to these units so that they can operate in a effective and efficient way. This way of working has been proven successfully in practice and we will illustrate it with 
a few examples. To make key ideas operational it is necessary to keep track of the differences between different types of processes: The BPR-literature has redefined companies into set of processes but is relatively silent about the complementary roles they play in setting up a processbased business unit. We suggest that a distinction between customer, development, planning and control, and staff and service (or enabling/supporting) processes. Furthermore, business processes also have to be defined in an industry or firm specific way to make them really operational.

Another issue to be dealt with is the question how process-based business units fit together to create a process-based corporation? This question has hardly been answered in the BPR-and change management literature. However, the recent work of Ghoshal and Bartlett (1997) provides an interesting framework to answer that question. Although their research is not about processbased companies, one can show that all management levels in performing process-based companies have to play completely different roles than in the traditional structure-based company. One can no longer think in terms of the traditional strategy-structure-systems doctrine which dominated management literature for almost half a century but has to emphasize the roles and tasks of different management groups. This has, in its turn, influence on the way the planning and control process is structured and implemented.

The paper is structured in the following way. In the next section, we clarify what a process-based organization is. Section three offers a framework contrasting structure-based and process-based companies. First, we analyze why structure-based organizations have problems to stay competitive in a complex and dynamic environment and why process-based organizations are likely to do better. Next, we enter the issue how to structure a business unit around processes and how a process-based organization has to be set up. In the fourth section, we deal with the difficult leap from process-based business units to a process-based corporation and its implications for the roles of top and middle managers. A concluding section summarizes the main managerial implications of setting up successfully a process-based organization.

\section{UNDERSTANDING PROCESS-BASED ORGANIZATIONS}

In order to distinguish process-based organizations from other types of organizations one has to start with the definition of business processes. Davenport (1993, p.5) defines a business process as " ....a structured, measured set of activities designed to produce a specific output for a particular customer of market". Hammer and Champy (1993, p.35) defines “... a business process as a collection of activities that takes one or more kinds of input and creates an output that is of value to the customer".

Most illustrated examples of business processes are order fulfillment, customer acquisition, manufacturing, product development, accounts payable, post-sales service, etcetera. (Davenport, 1993; Hammer and Champy, 1993). Setting up a process-based organization always starts with the identification of the key processes of the company. Usually firms - even multibillion companies - can draw a process map with only 5 to 15 key processes. Each process entails a number of activities or tasks: order fulfillment for instance is a process comprising tasks as receiving an order, entering it to the computer, checking the customer's credit, allocating inventory from stock, picking and packing goods, loading and sending them, etcetera. However, a thorough 
analysis of a company and its strategy quickly reveals that processes have to be defined in a firm specific way. As a result, there are several ways to define business processes and each type of industry or firm requires different sets of business processes. The examples in part 3 illustrate how processes have to be defined and described in a firm specific way.

Processes are at the very heart of every organization because they are the means through which companies create value for their customers. Major processes such as product development or manufacturing almost always draw on multiple functional skills. Other processes such as order fulfillment and post-sales services cross the external boundaries of the company. These processes are called value-adding processes because they directly create value for the external customer. But there are also enabling processes whose customers are within the organization. Examples are the process of developing and deploying IS, which supports a large part of a company's operating processes, and the process of personnel recruitment and development. They both do not create value for the customer but value-adding processes can achieve competitive edge only if they are supported by agile enabling processes (Hammer and Stanton, 1995).

However, it is useful to distinguish more types of processes in order to develop a process-based organizational structure (see part 3). Basically, we distinguish four types of processes. First, there are the customer processes which are those processes that add value for external customers. Second, development processes such as product development, product/market innovation, technology innovation etcetera allow the organization to work effectively on a longer time horizon. Actually the development processes have to be seen as value added processes, with a longer time horizon. These both types of processes are the raison d'être of a process oriented company and they are the basis around which organizational units are centered.

Next, planning and control processes focus on particular management tasks. It is useful to make a distinction between planning and control processes that are linked to the execution of the customer and development processes and those that arise from the requirement that separate parts of the organization function as a whole. Examples of the first type are the management of the relationship with suppliers, the management of distribution channels and label management. Examples of the second type are process management (the management over one integral business process) where integration over sub-processes takes places (e.g. logistic planning) and business planning and control (e.g. based on the balanced business scorecard). This last type of planning and control processes have an important integrative role. Within a process-based organization the contents and organizational positioning of these planning and control processes is of extreme importance. In our experience here also lies the biggest resistance to change, because it requires a different role of management and its supporting staff. We enter this issue in a more detailed way in part 4.

Finally, staff and service processes have to be recognized as well. They play a role as an enabler of all the other types of processes. Frequently cited examples are ICT, human resource management, finance and administration and maintenance. In a process-based organization the role of staff and service processes really are seen as enabling. In more traditional organizations staff and service departments (not processes) are power centers, because they take care of integration over organizational units. In a process-based organization the objective is to minimize the necessary integrative planning and control. This means that the role of staff and service 
changes dramatically compared to classically structured companies.

A process perspective necessarily entails cross-functional and cross-organizational change. Yet, in most companies no one is in charge of processes because the organization is divided into functional or product departments in which work is not organized around processes but around tasks. On the contrary, a process perspective is customer oriented and implies a horizontal view of the business that cuts across the organizational departments. Process owners have full responsibility for the effective and efficient running of a process. He or she guides the process team that can operate largely on its own. Consequently, management roles have to change drastically from budget planning and control to guidance and support for operational units. One of the major factors inhibiting these change and reengineering efforts is the existing organization structure. However, the literature is silent about what the implications for the organization structure might be if a company migrates towards a more process oriented organization.

\section{FROM CLASSICAL ORGANIZATIONAL STRUCTURES TO PROCESS-BASED STRUCTURES}

We analyze in the following what went wrong with structure-based organizations and why process-based companies are more likely to be competitive in a more complex and dynamic environment. Next, we focus on the question how processes can be translated into organizational units and how a process-based business unit can be set up. These issues are illustrated by means of a number of field cases from prominent Dutch companies. Finally, we tackle the problem of cross-process integration and elaborate on the role of planning and control processes.

\subsection{Classical organization structures}

Modern organizations have been organized according to the idea of specialization of labor of Adam Smith. This idea argues that processes have to be fragmented into simple tasks which are normally performed by one person. Accordingly, organizational structure reflected this functional approach and the management had to coordinate the functional operations. This functional organization has been reshaped into a multidivisional corporate structure for large firms since the experiments of General Motors and Du Pont in the inter bellum period. In the postwar period, most studies focused on the strategy-structure linkage, and, in particular, there was strong emphasis on the way in which the multidivisional model facilitated inter-industry and geographic diversification (Chandler, 1962). These diversification possibilities also changed the management roles. The divisionalized structure facilitated the diversification strategy by supporting expansion into new markets and products. Consequently, capital became a critical strategic resource and strategic planning was crucial as a management practice. The sophistication of capital budgeting systems and the growing influence of the headquarters stifled individual initiative and creativity at the SBU level.

As a consequence, the predominance of the strategy-structure linkage has also brought organization structures and charts into prominence as management instruments. The structural design accomplishes basically three tasks; designating the formal reporting relationships, 
identifying the grouping together of individuals into departments and departments into the organization, and designing the systems to ensure effective communication, coordination, and integration of effort across departments (Child, 1984). These tasks can be achieved in different ways: the two most common approaches to structural design are the functional and the product (multidivisional) structures. Hybrid structures and matrix organizations trying to combine the strengths of both types of structures are equally well known. Although these organization structures are quite different from each other, they share the same management philosophy; i.e. structure follows strategy and information, planning and control systems are the major tools to implement the desired organizational structure.

\subsection{The need for process-based organizations}

The fast changing demands of the business environment create an urgent need for organizations to break away from the traditional organizational model. Among the most important external forces were the globalization in many industries, the shortening of product life cycles, the convergence of technologies and the associated blurring industry boundaries, the massive deregulation in industries and the necessity to build up and renew technological capabilities to succeed in knowledge-intensive industries. Since the economic growth slowed down in the seventies and eighties and competition intensified, customers became more demanding. To become customer oriented was one of the major business challenges. Companies tried out different strategies within the existing organizational paradigm to cope with the new challenges of the external environment but they were only modestly successful: matrix organizations, decentralization, increased customer involvement and other corporate tune ups did not give satisfactory bottom-line improvements. The basic reason for the relatively poor results of these tune-ups is that the organizations structures are basically not changed; most organization structures are based on function or product or a combination of both. Instead of starting from what could add value for the customer and work backward from there, traditionally structured companies still attribute customers only a secondary role in shaping the way how the company organizes its activities.

Functionally organized companies have considerable problems taking a customer's perspective, because processes that produce value for the customer - e.g. order fulfillment - cut across several departments. However, the latter only report to higher-level managers, so that a customer perspective can be realized only at that level. Frontline managers will be reluctant to take the same perspective since they are not accountable for the outcome of other departments taking part in the same process.

Companies organized along product lines also have problems taking a customers perspective as well. A product structure leads to poor coordination across product lines which is a major drawback when divisions serve the same customers. Information systems in different units are likely to be incompatible with each other, resulting in a fragmented approach of customers, which, in turn, leaves lots of possibilities untouched to create value for them. Because most product divisions are functionally structured the same shortcomings of functionally organized companies are applicable on the business level of product-based companies. 
Process-centered companies have the ability to overcome this problems, since processes bring by definition the customer to the fore. Davenport (1993) argues that adopting a process view of the business implies that an organization does what is necessary to produce value for the customer. Traditional organization structures give a static view of responsibilities and reporting relation. On the contrary, a process-based view is a dynamic view of how the organization can deliver value.

Key processes are by definition cross-functional and will automatically de-emphasize the functional structure of company. As a result, taking a process-oriented view is basically incompatible with traditional organization structures. In that way, structuring along processes is completely different from redrawing lines and boxes in the organization chart. In the next section, the different dimensions of structuring along processes are explained.

\subsection{Structuring the organization along processes}

The BPR-literature has its focus almost entirely on business processes as unit of analysis. The implications of organizing a business unit around business processes has only be addressed by a few scholars (Davenport, 1993). In this section we analyze how an organization or a business unit can be structured along processes. First, we illustrate by means of a few examples how the organizational structure of a business unit may look like once a company has chosen to become process-based structured. Next, we enter the question how to set up a process-based organization. Finally, we briefly discuss cross-process integration and the role of planning and control processes.

\section{Processes and organizational units}

Redesigning a company towards a process-based organization implies that all activities, which logically belong together in order to create value for the customer, are grouped together. First, this means that the 'customer'-processes are defined and taken as the basis for an organizational unit. Second, we add the 'development'- and 'planning and control'- processes that are necessary for reaching the core objective of the unit. This implies that the organizational structure of a business or a company is based on organizational units which are organized around the core processes. Hence, process teams should be busy for $80 \%$ to $90 \%$ of their time to activities that belong to these core processes. The latter also represents at the same time the main objective of these units. The objectives of the different organizational units should be a part of the overall mission or strategy of the company, but this is achieved in a different way than in the traditional functional organization. Every organizational unit executes a well defined part of the customer processes (but always being a integral process) and so the objectives are always linked to customer value. Where for instance in the functional organization, objectives for an organizational unit, only can be linked to customer value by translating them (normally done top-down). Structuring a business or a company process-wise implies that coordination across process units is kept at a minimum. The following paragraphs illustrate how companies or business units can be structured around processes. 


\section{Example 1 : Banking}

A business of a Dutch bank was originally divided in commercial units with their own front and back office, which is illustrated in the first graph in figure 1. The front offices were basically busy with commercial activities such as sales and account management but a lot of the employees' time was taken away by non-commercial activities. Especially administrative, repetitive and time consuming activities were executed by the back-office. Within the commercial processes this resulted in a lot of transfer activities between front office and back office.

\section{Insert about here figure 1}

In the redesigned organizational structure commercial units can focus to a maximum on commercial activities, while almost all administrative activities are moved to a centralized operational unit, that executes activities for more than one commercial unit. The major concern of the bank was to have a clear interface between the commercial units and the operational unit in order to be sure that processes, where possible, were disconnected and units could work independent from each other. This also implied that an activity - e.g. administration - that was hard to attribute to a particular unit was split up into two separate parts. This required a thorough study of the processes and their interrelationships, because it had to be made sure that coordination between units was minimized. This resulted in service level agreements working both ways (the requirements with regard to the product that has to be transferred on the one hand and customer service requirements for the customer processes in the operational unit on the other hand).

\section{Example 2 : Computer services}

The second example illustrates a redesign of a computer service organization. The company sells a range of different ICT products/ systems, for instance cash desks (highly standardized and a large installed base) and large information systems (customer specific and normally combined with systems from other companies, including application software). The company faced serious competitive challenges as the different product types required different competencies to deal effectively with the customers' demands. High volume products like cash desk services required quick repair and repairs were evolving towards quick exchange of spare parts, while large information systems required highly skilled technicians to analyze and repair software and hardware problems, in strong cooperation with the clients systems managers.

\section{Insert about here figure 2}

This led to a dual approach as depicted in figure 2. The company was divided into two processbased teams: a high volume market covering the cash-desks and other comparable product lines, and the "named accounts" for the large information systems. The high volume market was composed of four units. First, customers could call a service desk that accepted and planned the call (and were responsible for the follow-up), secondly the problem was analyzed and if possible solved by a remote solution (an increasing part of the problems could be solved in this way). Subsequently, field engineers repaired the equipment if necessary by swapping spare parts. The named accounts required a completely different and sequential approach. An account manager first analyzed the problem on a general level, in strong cooperation with the client, followed by a specific (product oriented) problem analysis, if necessary. Hence, the logical process is the same 
for both product lines, but the way it is organized is completely different. Henceforth, it became clear that both process-based teams innovated their processes and services in very different ways, originating from the specific knowledge that was generated from a strong customer focus.

The consequences of these two types of service are significant. In the first case, a call center operated as a first unit accompanied by two other units, one that analyzed problems in the different product areas. There was no need that the engineers in these two units were highly skilled as they always could be assisted by a "technical and logistical support unit". The "named accounts" was structured in a different way. Here, problem analysis was crucial and highly skilled engineers were necessary to solve software or hardware problems. The service started with an account manager that analyzed the problem and went subsequently to software or hardware engineers depending on the nature of the problem (product specialists). Technical and logistical support was an integrated part of the job of these product specialists.

\section{Example 3 : Capital intensive production process}

A last example comes from a industrial company which produces household and personal care products like detergents and toothpaste. Promotional products accounts for $40-50 \%$ of total turnover. Management had a hard time combining the standard products with the promotional products within the same production process. This led to serious difficulties in meeting customers' needs.

After analyzing the problems the conclusion was that both processes should be dealt with in a different way. Both processes used shared resources with different operational objectives and required different contributions from sub-processes, as shown in the next figure. Before, both processes were treated in the same way and promotional products came on top of the standard process. This, while the promotional products added a lot of complexity and dynamics because of the low predictability, the higher customer demands, the consequences on the production process itself (especially within filling and packaging, because promotional products always asked for add-ins/add-ons/stickers). This made the production planning of promotional products very complex, where a strong relation with marketing and sales was needed. The suggested solution to the problem is illustrated in the following figure.

\section{Insert about here figure 3}

Because of the capital intensive production process it was not possible to make a distinction in two separate processes (as described in example 2), so a 'virtual' distinction was made, by changing the planning process. First the promotional products were planned (because of the higher complexity) and second the standard products were planned. If the utilization was too high or too low, only changes would be made in the planning of the standard products. To ensure that the right decisions would be made in the planning process the responsibility of the marketing and sales department was redefined. A supporting set of performance indicators was developed.

Setting up a process-based organization

After having redefined the key processes in an organization, a company can start to structure 
organizational units around processes. Setting up a process-centered organization is a major challenge because of the difficulties to implement it the right way. Majchrzak and Wang (1996) have shown that simply changing organizational structure from functional units into processcentered departments is not enough to guarantee improved performance. Departments should cultivate collective responsibility and a collaborative culture; shifting boxes on the organization chart alone cannot achieve these goals.

Setting up a process-centered organization is by most firms perceived as an unachievable target. In most companies, process management is overlaid as an additional dimension on the existing (functional) organizational structure. In this scenario, management hierarchy still holds the reins and process responsibility has no organizational legitimacy (Hammer, 1996; Davenport, 1993). However, a few Dutch examples show that it is possible to set up a fully process-based organization. We distinguish two key ideas underpinning a fully process-based company. First, the (one business) company is divided into basic organizational units which are organized around the core processes. This implies that the units are based on a customer oriented process and that the organization will be structured along the main objective of these units. Second, we gradually add other processes so that these organizational units can operate in the most effective and efficient way; first, development processes are added to these units minimizing the necessity of cross-unit coordination; second, the remaining control structure is set into place enabling the separate parts of the organization to function as a whole; finally, management has to tune up this organizational structure. The last part is necessary because the ever changing environment requires for competitive reasons to set up new processes or to change the old ones.

An recent example of a Dutch financial services company can illustrate this way to set up a process-based organizational structure. The company is considered to be a one business company offering different financial services. Previously, the firm had a strong functional organization and product groups were financially responsible. The management decided that the company should be restructured as a process-centered firm. Three customer-core-processes were distinguished around which the organizational units could crystallize. The first one (unit one in figure 4) consists of several "market teams" whose main objective is to acquire new customers and to extend the range of products sold to existing customers. These "market teams" are market oriented and each one focuses on another target group. Their size and structure can be very different ranging from a completely standardized unit with a large customer base to a small experimental unit for a particular type of customer, with very specific demands. Examples of these "market teams" are intermediaries, collectives/companies, direct marketing and private labels. The two other units are each responsible for one customer-core process for all the customers of the teams in unit 1 . In contrast with unit 1 which is aimed at different operational target groups, the other two units try to benefit to a maximum from standardization and economies of scale, but being flexible enough to cope with the specific requirements of a particular target group.

\section{Insert about here figure 4}

Figure 4 shows the organizational structure of this financial services company based on the customer-core-processes. There are basically three organizational units which are centered around primary, customer oriented processes (bold text in figure 4). The first unit (unit one) focuses on market oriented commercial services and the productising of core products. Process teams are 
responsible for the advice and sales processes vis-à-vis particular target groups, they have to cope with commercial management, total customer treatment from a commercial point of view and risk evaluation (within standards). The second unit specializes in customer care processes (with direct client contact) and damage control. The last unit is responsible for the different product lines from a technical point of view. Customer contact originates from bills to be paid for expenses paid for by the customer and standard changes in the contracts (e.g. name, address etcetera).

The second step consists of adding development processes (bold and italics) to these three organizational units. These processes are added to a unit when it is necessary for its main objective and when this way of working can guarantee a minimum of coordination costs among units. Market teams in the first unit are responsible for their own productising of the existing products with respect to a particular target group. The second unit has the responsibility to organize the infrastructure needed for the delivery of customer care including the contracting and purchasing processes. The third unit is responsible for technical product development and price setting (this does not include the commercial price setting). New product/market innovation, product development and concern-marketing processes are considered to be processes that are hard to assign to one unit and are therefore organized within a central product-marketing unit.

Next, planning and control processes (italics) are added to the different units. Those that are of value for the three units are centrally organized: the central product-marketing unit is responsible for label management and the central management unit takes care of support of business control and management information. The development of a consistent set of objectives and performance indicators is essential to make sure that the different organizational units will function as a whole. It will be clear that the set of objectives for every organizational unit will be different from the ones used before, because objectives are divided in a different way.

Finally, staff and service processes (plain text) complete the picture. Examples are information and communication technology, human resource management and a service unit that is responsible for the financial administration, public relations, legal affairs, etcetera. Employees of the service unit can be located in one of the three units but they are under the authority of the central service unit.

\section{Process-based companies and cross-process integration}

Redesigning an organization or a business unit from a functional or product structure to a processbased one does not mean that one can abolish the organizational structure completely. Being organized along processes does not imply that organizations can be designed upon organizational processes only, and it is hard to imagine how real business units can be defined as networks of processes, which are unified through the mere fact that they share common objectives, as suggested by Simon (1995).

Creating a process-based firm does not mean that organizational structure has to be abandoned as has been illustrated in the example of the financial services company. Davenport (1993, p. 160) argues that process-based organizations "...are a powerful compromise between the need to maintain structure and the desire to adopt a flexible approach to the way work is done". 
Davenport and Nohria (1994) for instance show that extensive case management replaces some functions, especially when expertise levels needed to perform the tasks are low. In other cases it leads to a shrinkage of the number of functional experts; this is the case when expertise can be taught to case managers or put into information systems. Finally, some functions are left completely intact.

As a result, processes cannot become the only basis for organizational structure. Functional and product oriented skills remain very important in a process-based organization, so that most firms will have to adopt a multidimensional matrix structure in which process responsibility is a key dimension. Furthermore, activities can fall between the cracks of processes in the same way as they did between functions in a functional based organization. As a result, a fully process-based organization will have to pay attention to possible cross-process integration.

The example of the Dutch bank (figure 1) illustrates this need to integrate over processes. This examples shows how important it is to have a clear-cut interface between the commercial units and the operational unit. If responsibilities of the two types of units are not sharply defined a number of activities can fall through the "cracks" of the two process-based units. But problems remain even if the interface is carefully designed. Take for example "administration"-activities. Previously, the front office was responsible for these activities. After the reorganization these activities were split into "commercial administration" and "operational administration". It is obvious that these two types of administration-activities require careful management and integration across the two process-units.

\section{Planning and control}

A process-centered organization (or business unit) requires a set of complementary processes that have to fit together in order to function as a whole. Although process owners en process teams are supposed to incorporate a high degree of self-management there is some agency required to bring the different processes together and make sure they operate in a effective and coherent way (Hammer, 1996). Since process-based organizations are built up around independent processes and autonomous organizational units this requires a strong emphasis on the development of coherent sets of objectives and performance indicators for each unit. They should be derived directly from the strategy by linking the strategic choices to the customer processes and development processes. As shown the units are constructed in a way that day-to-day coordination is minimized. To make this work it is essential that management takes time for defining the objectives for the units and for executing the process of business control. This is were integration takes place. But maybe this exactly is what management should be doing in order to create the conditions for frontline management to get the best results within a demanding and dynamic environment.

\section{THE LEAP FROM PROCESS-BASED BUSINESS UNITS TO A PROCESS- BASED CORPORATION}

BPR-literature usually restricts itself to the business-level implications of structuring a company 
along processes (Hammer and Champy, 1993; Hammer and Stanton, 1995; Johansson et al., 1993; Andrews and Stalick, 1994). More recent literature (Hammer, 1996; Beer et al., 1994; Ghoshal and Bartlett, 1997) shows that process oriented business - or empowered frontline managers in general - is necessarily linked to particular corporate strategies and management roles at the top level. The following paragraphs focus on the management implications on the corporate level.

As many firms move toward the integration instead of the division of labor, jobs and the way how employees collaborate change dramatically. The implementation of multi-disciplinary, cross-functional process teams is one of the crucial success factors of the evolution to a processbased organization. These teams give more responsibility, decision making power and flexibility where it is needed, so that the organizational performance increasingly depends on process teams and individual employees working within these teams. Jobs become more complex and more challenging in process-based organizations. Employees have to be empowered as their work is more self-directing.

Effectively working process teams can improve the organization of the process or they can adjust it swiftly to changes in the market place as they have to a large extent autonomy over the process. This continuous adaptation and change implies that process teams become learning centers with improved change capability over time. Recent literature on competence-based competition emphasizes the role of change capabilities (or dynamic capabilities) in strategic management (Lei et al., 1996; Teece et al., 1997). However, process teams do not develop spontaneously competence enhancing learning behavior. Too many re-structuring efforts in the past overlooked the management of team-based processes and human change (Davenport, 1996; Kennedy, 1994).

Similarly, process owners and frontline managers are the company's entrepreneurs within a process-based organizations: they are the closest to the process teams and the customers, they know the competitors best and are knowledgeable about the best-practice technologies in their industry. However, frontline managers resign themselves to the role of operational implementers if direction and control from above is too autocratic. Whyte (1956) powerfully argued that modern (structure-based) corporations had subjugate individual initiative and creativity to the perceived greater need for consistence and control.

Shifting from a structure-based to a process-based organization model implies that middle and top management roles have to be changed drastically. It is at least surprising that most publications about process-based companies do not elaborate on this topic in a fundamental way. They focus mainly on the role of management during the transition phases of BPR or change projects and on the drastic effects of delayering on middle management (Hall et al., 1993; Grover and Kettinger, 1995; Hammer and Stanton, 1995; Kennedy and Harvey, 1997). Management implications for process owners and frontline managers have been amply described in the literature, but the implications for top and middle management have been less clear. Usually, scholars come up with several rules of thumb for transitions to process-based firms - i.e. strong commitment of senior executives, the formulation of a vision, etcetera. Hammer (1996) deepens the level of analysis by asking a more fundamental question: How do process-centered business units fit together to create a process-centered corporation? His answer, however, gets stuck into the traditional centralization-decentralization debate and does not cope with senior management 
implications.

Ghoshal and Barlett (1997) do not particularly focus on process-based organizations but their view on management roles is completely in line with the requirements of a process-based company. They argue that companies have to change the behavioral context - the way individual organization members behave and act - in order to remain vital. They no longer conceive viable companies in terms of their formal structures and organization charts, but as portfolios of core organizational processes that overlay and often dominate vertically, authority-based processes of the hierarchical structure. These authors describe three core organizational processes: the first one is the entrepreneurial process which develops and supports opportunity-seeking, externally focused frontline managers. The integration process intends to overlay scale and scope advantages with those related to flexibility and responsibility. Finally, the renewal process creates and sustains the dynamic capabilities of the company, thereby revitalizing business strategies (Ghoshal and Barlett, 1997 p. 191).

In the traditional company top-level managers act as chief corporate entrepreneurs, setting corporate strategy and implementing it by means of strategic planning tools. Middle managers played the role of administrative controllers and frontline managers became mere operational implementers. This set of management roles are at odds with the basic assumptions of a processbased organization. Parallel with the management roles described in Ghoshal and Bartlett (1997) one can summarize the new roles as follows: frontline managers are no longer the implementers of top-down decisions but they become the primary initiators of entrepreneurial action. Thanks to the customer oriented process structure, process teams and owners are ideally placed to observe the ongoing changes in the economic environment and to evaluate changing needs of the customers. They might also be very well aware of potential new markets, products or customers. Releasing their entrepreneurial forces is one of the major requirement of developing and sustaining competitive process-based companies. In this respect, middle managers become key resources to frontline managers, coaching and supporting them in their activities. They also link dispersed knowledge, skills and best practices across businesses. Overall, they play the role of capability developers integrating the diverse capabilities of several process oriented business. Within this context, top management no longer acts as corporate entrepreneurs controlling strategic content but they create an overarching corporate purpose and ambition which challenges the existing operations and strategies. They shape the organizational context and create the challenge and commitment to drive change.

Many top-managers of companies that switched to a process-based organization recognized that frontline managers have to be empowered in order to stimulate them to act in a more entrepreneurial way. This requires that the structural hierarchy pyramid is inverted, so that the process-based business units become the basic structural unit shifting the locus of power "down" in the hierarchy. Inverting the pyramid has been a popular idea within companies that were going through a restructuring, delayering and downsizing process. Many of them have experienced that cutting costs and enhancing productivity does not necessarily result in a stronger competitive position in the long term and may even trigger new rounds of downsizing leaving the company in a state of organizational anorexia.

It takes more for a revitalizing or growth strategy than simply empowering frontline managers and 
inverting the pyramid. Middle- and senior-level staff as well as line jobs have to be redefined as has already been illustrated. At the same time, frontline entrepreneurs do not have the ability to integrate capabilities and best practices, developed in a particular business unit, across different businesses and countries. The role of middle and top managers has to be redesigned to develop and sustain these coordination mechanisms. They no longer control but support the frontline entrepreneurs, they become their developmental coaches. In this way, the organizational configuration changes from an inverted pyramid into an integrated network which is conducive to both the blossoming of frontline entrepreneurship and cross-unit learning.

In structure-based organizations strategy and organizational structure are intertwined; control over the company's structural configuration was a powerful tool in shaping corporate strategy in traditionally organized firms (Chandler, 1962; Rumelt, 1974). The new role of three levels of management which are required in process-based organizations forces these firms to break away from the tied linkage between strategy and structure: not the formal structure of a divisionalized hierarchy per se is to blame but the roles and tasks of different management levels that went along with that structure. The traditional organization chart can no longer explain the way how processbased firms function: it still illustrates accurately the formal responsibility-based relationships among managers, but redrawing the boxes and lines of the formal organization will not necessarily add value in terms of the company's competitive strengths. As we have argued in line with Ghoshal and Bartlett (1997), the role of the different management layers in successful processbased corporations can only adequately been visualized by means of an integrated network. As a result, one can make the conjecture that within process-based organizations the linkage between strategy and structure will be mediated by the way how management roles are defined.

\section{CONCLUSIONS}

Process-based companies have become fashionable during recent years. They are a powerful answer to the problems functional and product oriented structured firms faced. Despite its success the literature on process-based companies has blind spots when it comes to setting up a processbased business unit or organization starting from process teams. One of the related issues that deserves much more attention is the way how process-based organizations are structured.

In this paper, we argue that process-based organizations also have a completely different organizational structure than structured-based ones. We try to avoid two extreme points of view: on the one hand, processes cannot become the only basis for organizational structure because functional skills as well as product management remain important. Not all activities can be aligned along processes, so that cross-process integration would be necessary in a purely process based company. Furthermore, a number of control and planning activities are required on a higher level than the processes. On the other hand, most firms engaged in setting up a process based business-unit or company simply impose process management as an additional structural dimension on top of the existing functional or product dimension. In that way, being structured in a process-based way conflicts with the other dimensions and process responsibility does not get any organizational legitimacy. Therefore, we suggest that a multidimensional structure with process ownership as a dominant dimension is a viable solution for many companies. 
A few field cases illustrate how process-orientation can be translated into organizational units. Two key ideas are at the basis of what a viable process-based organization might be. First, a company is divided into basic organizational units which are organized around core processes. Second, other type of processes are added to these units so that they can operate in a effective and efficient way. To make key ideas operational it is necessary to make a distinction between different types of processes and to look for the complementary roles they play in setting up a process-based business unit. Furthermore, processes become operational only if they are defined in an industry or firm specific way: this is because core processes are derived from a corporate or competitive strategy which is by definition tied to particular characteristics of the company and the industry.

Process-based business units also have to fit together to create a process-based corporation. This topic has not been analyzed thoroughly in BPR- and change management literature. Ghoshal and Bartlett (1997) provide an interesting framework. Although their research is not about processbased companies it is applicable to large process-based companies. We argue, in line with these authors, that middle and top management in process-based companies have to play completely different roles than in the traditional structure-based company. The way how a process-based corporation is structured can no longer be conceived within the traditional strategy-structure paradigm where top management developed the strategy and implemented it in a strict top-down fashion by means of a complete set of planning and control tools. Top and middle management in a process-based corporation is much more supportive; it basically stimulates frontline entrepreneurship and integrates dispersed knowledge and best practices across business units. This new role of the different management levels allows a company to be more responsiveness to new competitive requirements that may quickly change in complex and dynamic environments. In this way process-based companies may have stronger dynamic capabilities than traditionally structured companies. 


\section{BIBLIOGRAPHY}

Andrews, D.A. and Stalick, S.K. (1994); Business reengineering: The survival guide, Englewood Cliffs, NY: Prentice-Hall.

Bartlett C.A. and S. Ghoshal (1995), "Rebuilding behavioral context: Turn process reengineerin)g into people rejuvenation", Sloan Management Review, Fall, pp. 11-23.

Beer, M., R.A. Eisenstat, and B. Spector (1990); The critical path to corporate renewal, Boston:Harvard Business School Press.

Chandler, A. (1962), Strategy and structure, Cambridge, Mass: MIT Press.

Child, J. (1984), Organization, New York: Harper \& Row.

Davenport, T. H. (1993), Process Innovation - Reengineering Work through Information Technology, Cambridge, Mass: Harvard Business School Press, 335 p.

Davenport, T.H. (1996); "Why reengineering failed: The fad that forgot people", Fast Company, Premier Issue, p. 70.

Davenport, T.H. and N. Nohria (1994); "Case management and the integration of Labor", Sloan Management Review, Winter, pp. 11-23.

Grover, V. and W.J. Kettinger (1995); Business process change; Reengineering concepts, Methods and Technologies, IDEA Group publishing, London.

Ghoshal, S. and C.A. Barlett (1997), The individualized corporation: A fundamentally new approach to management, New York: HarperBusiness, 353 p.

Hall G., J. Rosenthal and J. Wade (1993); "How to make reengineering really work", Harvard business review, November-December, pp. 119-131.

Hammer (1996), Beyond reengineering, New York: Harper Collins Business, 285 p.

Hammer, M. and J. Champy (1993), Reengineering the Corporation: A Manifesto for Business Revolution, London: Nicholas Brealey Publishing, 223 p.

Hammer, M. and S. Stanton (1995), The reengineering revolution: A handbook, Harper Business, New York, 335 p.

Johansson, H.J., P. McHugh, A.J. Pendlebury and W.A. Wheeler (1993), Business process reengineering: Breakpoint strategies for market dominance, Chichester: Wiley.

Kennedy, C. (1994); "Re-engineering: The human costs and benefits", Long Range Planning, Vol 27, No 5, pp. 64-72. 
-Kennedy, C. and D. Harvey (1997); M anaging and sustaining radical change, Business Intelligence Limited.

Lei, D., M.J. Hitt and R. Bettis (1996); "Dynamic core competences through meta-learning and strategic context", Journal of Management, 22, pp. 549-569.

Majchrzak, A. and Q. Wang (1996); "Breaking the functional mind-set in process organizations", Harvard Business Review, September-October, pp. 93-99.

Rumelt, R.P. (1974); Strategy, structure and economic performance, Boston:Divison of Research, Harvard Business School.

Simon, K.A. (1995); From structure to process: A vision of a process-based organization, Paper presented at the ENTER95 conference, Innsbruck.

Teece, D.J., G. Pisano and A. Sheun (1997); 'Dynamic capabilities and strategic management”, Strategic Management Journal, 18, pp. 509-533.

Whyte, A. F. (1956), Organization man, New York:Simon and Schuster. 
Figure 1: The process based organizational structure of a business unit in a bank

\section{From}

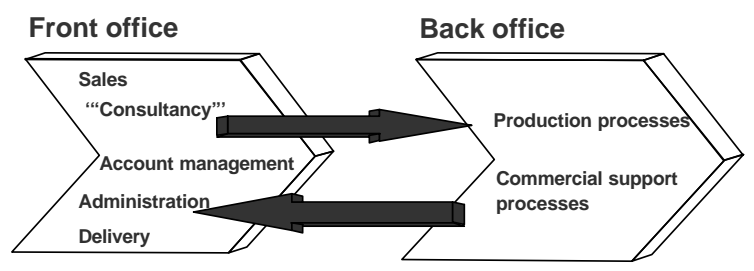

To

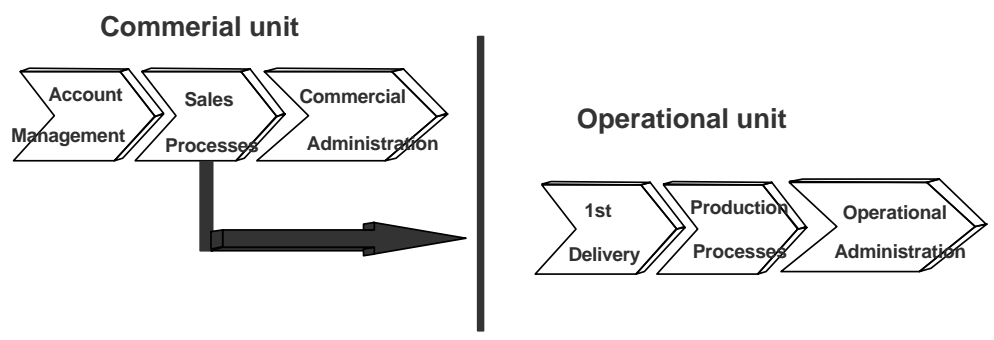

$-18-$ 
Figure 2: An example of two service formulas/teams in a computer service company
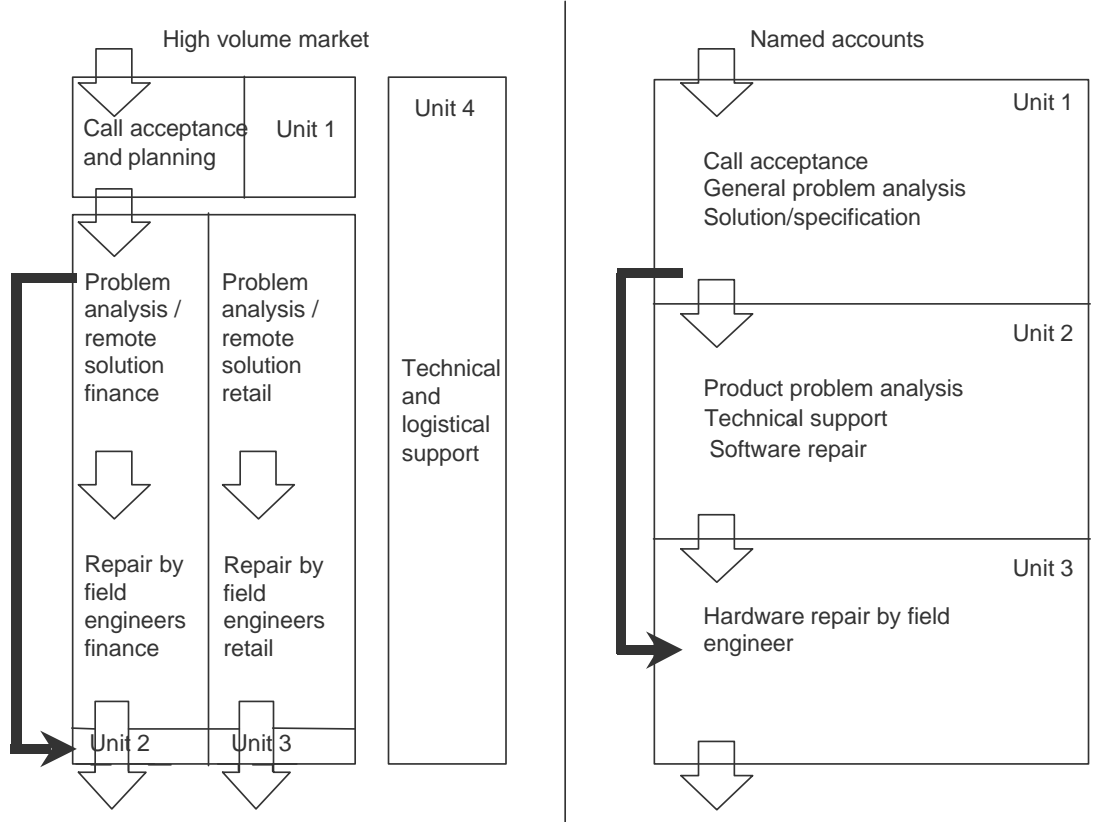

$-19-$ 
Figure 3: An example of two different industrial processes

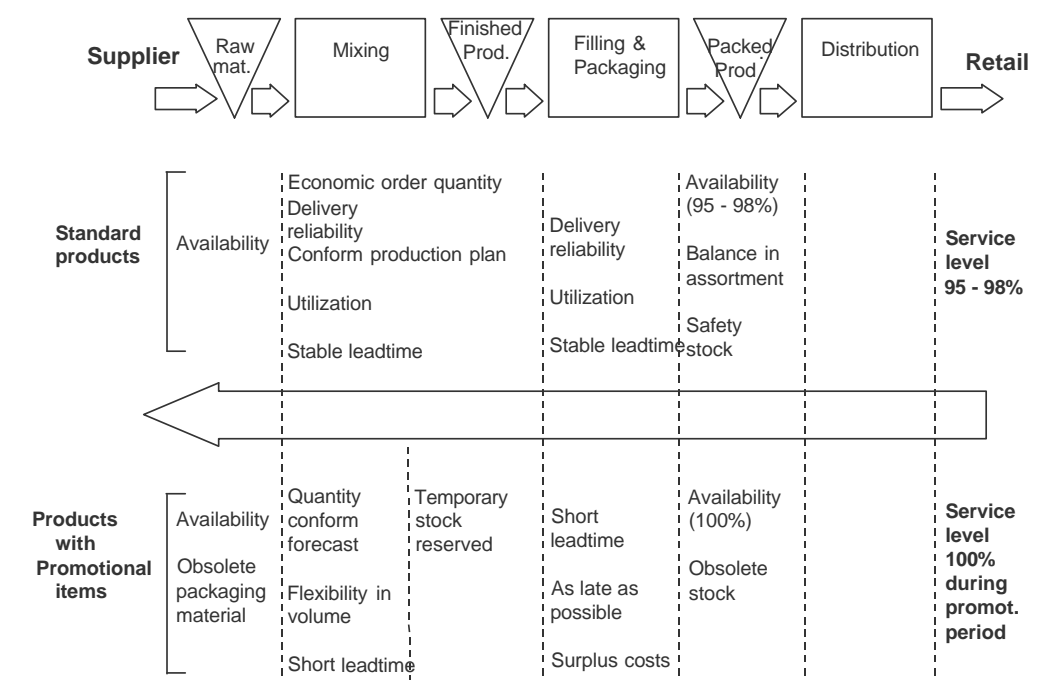


Figure 4: The process based organizational structure of a financial services company

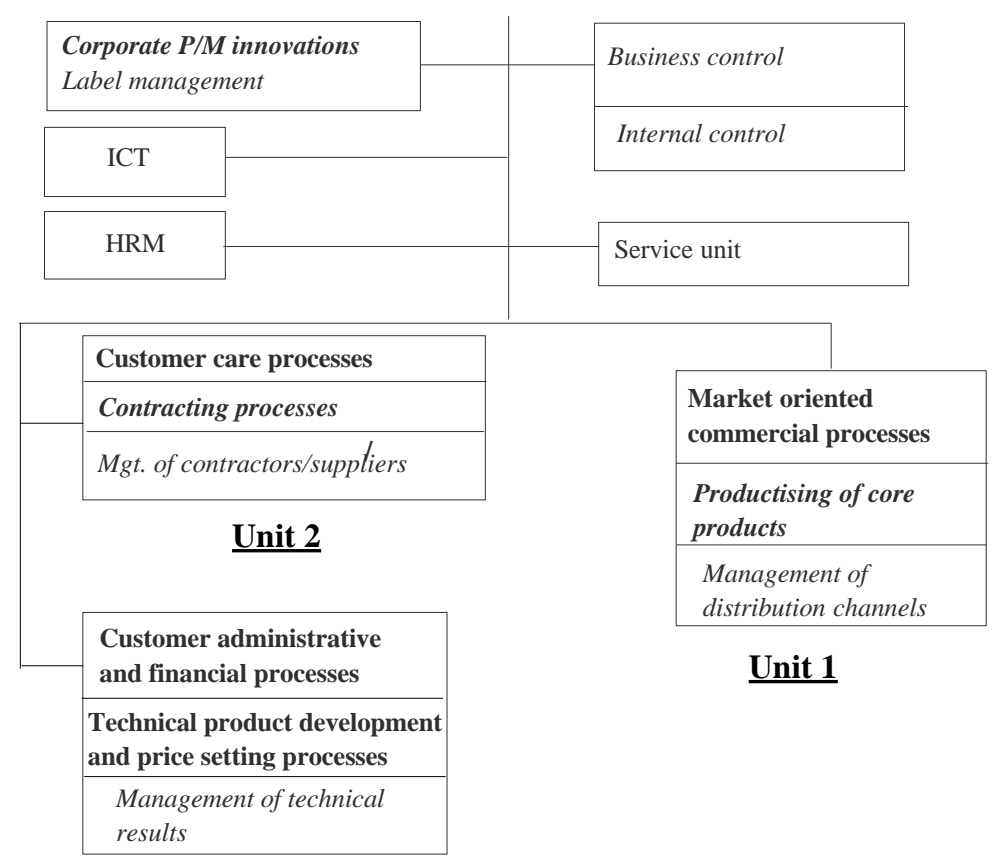

$\underline{\text { Unit } 3}$ 